\title{
Indigenous Live Feed for Aqua-Hatchery Larval Rearing of Finfish and Shellfish: A Review
}

\author{
Altaff K. \\ Department of Marine Biotechnology, AMET University, Chennai - 603112, India
}

Received: $3^{\text {rd }}$ April, 2020

Accepted: $1^{\text {st }}$ May, 2020

Published online: $7^{\text {th }}$ May, 2020

https://doi.org/10.33745/ijzi.2020.v06i01.013

\begin{abstract}
Production of animal protein through aquaculture is one of the vital sources to meet the future food challenges for the increasing human population. Commercial scale farming of marine finfish is one of the food security measures but their seed production technology is yet to be established. Even though marine finfish such as sea bass, milk fish, mullet, grouper and cobia are successfully bred and spawned under captive condition, their commercial level larval rearing is not achieved due to lack of species specific live feed. Currently, micro algae, Brachionus plicatilis and Artemia nauplii have been used as live feed in fish hatcheries which gives desirable results for limited number of cultivable species. For enhancing the farming of more number of finfish and shellfish nutritionally compatible indigenous live feed is needed to be mass cultured. The planktonic organisms such as microalgae, infusorians, rotifers, cladocerans and copepods constitute potential live prey for a wide variety of cultivable aquatic species. The size range and nutritive value of these live preys have specific biochemical profile which could be used for supporting normal growth and survival of the larvae of cultivable species. Considering the importance of live feed, there have been many published reports on the life cycle, nutritive merits and mass culture technology of microalgae and zooplankton for sustainable aquaculture. This article reviewed the biology, nutritive value and culture methodology of live feed organisms for hatchery rearing of finfish and shellfish larvae.
\end{abstract}

Keywords: Aquaculture, Live feed, Fish, Larval rearing, Hatchery rearing, Zooplankton

Citation: Altaff K.: Indigenous live feed for aqua-hatchery larval rearing of finfish and shellfish : A review. Intern. J. Zool. Invest. 6 (1): 162-173, 2020. https://doi.org/10.33745/ijzi.2020.v06i01.013

\section{Introduction}

For the past three decades aquaculture has gained importance and many marine and estuarine cultivable species of finfish and shellfish have been domesticated and their captive development of brood stock, breeding and spawning technology has been well established. As a result of this biotechnological development, commercial 
scale production of seeds of many fish and shellfish in the hatcheries is practiced all over the world (Lavens and Sargeloos, 1996). Large quantum of larvae of molluscs, shrimps and fish are reared and farmed leading to production of the animal protein (Lavens and Sargeloos, 1996). The larval rearing under hatchery conditions is carried out following species specific procedures due to variation in their larval size, small gabe, fragile nature, extent of receptors and digestive system development. For commercial level seed production appropriate technology pertains to aseptic condition, maintenance of water quality and feeding strategies need to be adopted. In this regard the larval nutrition in general and that of the sensitive first-feeding larvae in particular, has become one of the major bottlenecks which prevent the full commercialization of many cultivable finfish and shellfish species (Stottrup and McEvoy, 2003).

Different species of finfish and shellfish show preference of different feeding and breeding grounds in natural water bodies but all the fishes require protein rich live food for their better growth, efficient breeding and survival (Stottrup and McEvoy, 2003). The larval development of finfish and shellfish show species-specific variations for example, in the case of shrimp species the developing larvae have to pass through naupliar, zoeal and mysis stages leading to post-larvae. During the course of development the larva follows first an herbivorous filter feeding and then to a carnivorous with predatory behaviour (Bengtson, 2003). While summarising the feeding habits of larvae, Lavens and Sorgeloos (1996) reported that the mouth size of the larvae at first feeding stage is one of the factors which mechanically restrict the size of the food particles which can be ingested. The mouth size is correlated with body size, which in turn is influenced by egg diameter and the period of endogenous feeding. The developmental status of the digestive system of the first feeding larvae also indicates the ability of the larvae to digest the ingest food. It is well established that the live food organisms meet all the necessary criteria for the small larvae of all commercially important fishes. Further, for food to be ingested by a larva, it first has to be detected, and hence the degree of development of the functional sense organs such as the eyes, olfactory organs, taste buds and lateral line system is crucial. Occurrence of mostly cones in the retina of eyes of fish larvae provides poor visibility, while the eyes of juvenile fish contain rods with higher concentration of visual pigments which provide better vision. Live food organisms usually have a much better contrast than artificial feeds and generally have a triggering effect by their continuous movement, allowing an enhanced perception by the feeding larva. Likewise, the swimming activity of live food organisms generally assures a good distribution of food items in the water column, which facilitate frequent encounters with the developing larvae. Among different finfish and shellfish considerable variation is also observed with regards to the duration of their development period from hatching to metamorphosis.

The rotifer, Brachionus plicatilis and brine shrimp (Artemia) nauplii are most widely used live feed in aqua-hatcheries for the first exogenous feeding marine finfish larvae. However, these live feeds have been often reported to be inappropriate for many commercially important edible and aquarium 
marine finfish species (Dhert, 1996). As a consequence, achieving hatchery production of many marine finfish larvae to the commercial scale using either rotifers or Artemia nauplii is not successful. This constraint puts great impediment in the expansion of marine finfish production through mass culture. The identification of indigenous alternative live feed which is having suitable size spectrum and nutritive value for promoting desirable growth and survival rate of marine finfish larvae is highly essential for the sustained development of mariculture industry. This has been evidenced by the studies on the larviculture of Lates calcarifer (Rajkumar and Kumaraguruvasagam, 2006; Santhanam and Perumal, 2012), Amphiprion klarkia (Olivotto et al., 2008) and marine ornamental fish (Olivotto et al., 2010).

The live food organisms contain all the essential nutrients such as proteins, lipids, carbohydrates, vitamins, minerals, amino acids and fatty acids as per the requirement of developmental stages of most of the commercially important cultivable species. In order to achieve high and sustainable production of seeds of finfish and shell fish, nutritional requirement of individual species should be identified and quantified (Dharani and Altaff, 2004 a). Further, appropriately sized and nutritionally suitable food should be used to rear the different developmental stages of the cultivable species to achieve higher growth and survival of the larvae. If there is any deficiency, nutritional status of live food organisms should be improved through enrichment and bioencapsulation (Rasdi and Qin, 2016). With regard to ornamental fish production, at present mostly inert food items such as egg yolk suspension, milk powder or powdered feeds and natural plankton bloom induced by artificial fertilisation of water are used in larval feeding. These traditional practices not only limit the fish stocking density, but also adversely affect fish quality. Dhert (1996) opined that due to lack of suitable live feed for feeding early fish larvae with small mouth, sustained production of their stock is hampered.

Live Feed Organisms:

Live food organisms include both phytoplankton and zooplankton. Phytoplankton consist of chlorophyll bearing microalgae and zooplankton mainly comprises protozoans, rotifers and the planktonic forms of crustaceans, cladocerans, ostracods and copepods and their larvae. (Das et al., 2012). Among the many live feed organisms in natural waters, the role of some of the important groups such as microbes, microalgae, infusorians, rotifers, cladocerans and copepods is reviewed in this article.

\section{Yeast and Bacteria:}

Yeast constitutes one of the basic feeds in aquaculture and used directly for feeding fish and shrimp larvae. The common species used is Saccharomyces cerevisiae. Yeast forms ideal food for many zooplanktonic organisms and important ingredient of formulated feed for larval stages and farming species. $\Omega 3$ Yeast 60 is a selected yeast-strain which contains highest level of protein associated with essential fatty acid (EFA) and vitamin C comparable to the levels found in live microalgae. The b-glucans and mannan oligosaccharides content of yeast are immunostimulating compounds (White et al., 2002). In Brachionus plicatilis culture $\Omega 3$ Yeast 60 can support fast growth at high densities 
for long period of time, without presenting the risk of rotifer degeneration or culture crashes and hence yeast is still applicable in comparison to other commercial feeds in rotifer culture (Conceição et al., 2016). The mannan oligosaccharides, a natural sugar derived from the outer cell wall of some strains of Saccharomyces cerevisiae have been reported to benefit gut health and the immune system of shrimp and fish.

In aquaculture, bacteria is used as probiotics in the feed, as food supplement in fish culture and also as a prophylactic measure in live food production to stabilize and promote larval rearing through a microbiologically balanced system. The probiotics mostly used in aquaculture belong to Large Coccoid Bacterium (LCB) of the genus Bacillus and common species are Bacillus subtilis, Bacillus polyriyxa and Bacillus negaterium. These bacteria are consumed by several groups of zooplankton like protozoans, rotifers and copepods. The bacterial cells have good nutritional value as they contain essential amino acids, proteins and polysaccharides. Being a rich source of exogenous enzymes, bacteria also helps in digestion and absorption in the gut of larvae or food organisms. In larviculture, probiotic treatment results in better growth rate, survival and disease resistance in larvae (Verschuere et al., 2000).

\section{Microalgae:}

In nature, phytoplankton plays a significant role in stabilizing the whole pond ecosystem and in minimizing the fluctuations of water quality. A suitable phytoplankton population enriches the system with oxygen through photosynthesis during day light hours and lowers the levels of carbon dioxide, ammonia, nitrite, hydrogen sulphide and methane (Muller-Feuga et al., 2003). The desirable phytoplankton bloom can reduce toxic substances since phytoplankton can consume ammonia-nitrogen and tie-up heavy metals. A healthy bloom also provides proper turbidity and subsequently stabilizes shrimp and reduces cannibalism (Peter, 1996). It decreases temperature loss in winter and stabilizes water temperature. Phytoplankton also competes for nutrients with other microbes and lowers pathogenic bacterial population while increasing the density of food (Peter, 1996).

Dhert and Sorgeloos (2003) opined that the microalgae are an essential food source in the rearing of all stages of clams, oysters and scallops, the larval stages of some marine gastropods, larvae of marine finfish and shrimps. Zooplankton such as rotifers, copepods, cladocerans and brine shrimp also depend on algae as essential food. Thirty two genera of algae are cultured and used to feed different groups of commercially important aquatic organisms (Muller-Feuga et al., 2003). They include species of diatoms, flagellated and green algae, and filamentous blue-green algae, ranging in size from a few micrometers to more than $100 \mu \mathrm{m}$. The most frequently used species in commercial mariculture operations are the diatoms, Skeletonema costatum, Thalassiosira pseudonana, Chaetoceros gracilis, Chaetoceros calcitrans, the flagellates Isochrysis galbana, Tetraselmis suecica, Monochrysis lutheri and Chlorella spp. Algae can be produced using a wide variety of methods, ranging from closely-controlled laboratory methods to less predictable methods in outdoor tanks (Eryalcin, 2018). The different type of algal culture include indoor or outdoor, open or closed and axenic 
or xenic. The three basic types of phytoplankton culture which are in practice are batch, continuous, and semi-continuous culture.

The nutritional value of any algal species for a particular organism depends on its cell size, digestibility, production of toxic compounds and biochemical composition. Microalgae grown to late-logarithmic growth phase typically contain 30 to $40 \%$ protein, 10 to $20 \%$ lipid and 5 to $15 \%$ carbohydrate (Wang et al., 2016; Brown et al., 1997). Microalgae contain PUFA such as docosahexaenoic acid (DHA), eicosapentaenoic acid (EPA) and arachidonic acid (AA) which are known to be essential for various larvae (Sargent, 1997). The vitamin content of different species of microalgae shows variation. Most of the microalgae are rich source of ascorbic acid. Importance of microalgae in aqua hatcheries not only owes its nutritional attributes but more so for its small size ranging from 5 to 25 microns meeting the feed size requirements ideally for early stages of various aquatic animals organisms (Muller-Feuga et al., 2003).

\section{Zooplankton:}

In nature, zooplankton is one of the primary foods of fish larvae. The common groups of zooplankton are protozoans, rotifers, cladocerans, copepods, ostracods and larval forms of many invertebrates. Two of the dominant zooplankton groups are rotifers and copepods. These two groups are the preferred prey for shrimp and fish and are the most widely used live feeds by aquaculturists (Bengtson, 2003). The intensive larval culture of most marine finfish depends on a large supply of zooplankton to feed the delicate larvae, juveniles and even adults of fish, prawn and shrimp. In nurseries and grow-out ponds protein-rich and naturally occurring zooplanktonic organisms are essential. Different types of zooplankton like larval forms of brine shrimp (Artemia salina), rotifers (Brachionus sp.), cladocerans (Moinasp., Daphnia sp., Ceriodaphnia sp.), copepods (calanoid, cyclopoid and harpacticoid) and larval forms of different aquatic organisms are considered as natural food for the shellfish and finfish and mass cultured for hatchery use (Mehraj-Ud-Din and Altaff, 2010). Marine copepods are the most abundant metazoans throughout the world's ocean and constitute the majority of plankton biomass in the epipelagic zone. Their importance as natural prey items, in addition to their ubiquitous distribution in marine systems, makes them valuable live feed candidates for marine hatcheries, and their superiority over traditional live feeds is well established (Dhert and Sorgeloos, 2003). Among copepods, families from the genus calanoid possess fully pelagic developmental stages and are considered to have the best potential as live prey for fish and shrimp larvae. Recently, culture of cladocerans, Daphnia carinata, Ceriodaphnia cornuta and copepod Thermocyclops decipiens using organic manure produced high density of Ceriodaphnia cornuta than Daphnia carinata and Thermocyclops decipiens (Paray and AlSadoon, 2016). Production of the three species of zooplankton (Moina micrura, Scapholeberis kingi and Brachionus calyciflorus) using cow dung and oil cake as a resource for the growth of the zooplankton was reported (Kar et al., 2017). It provides an economic means of culturing the zooplankton at large scale for supporting the growth of the juveniles of the freshwater fish species. 


\section{Protozoans:}

The infusorians belonging to the class Ciliata constitute potential live food organisms in aquaculture. Besides being small in size, they are soft bodied and nutritionally very rich and hence serve ideally as starter diet for early stages of fish larvae. In the early developmental stages of fish larvae with small mouth size, infusorians are indispensable food. Marine ciliates were mass produced and offered for first feeding finfish and shrimp larvae (Nagano et al., 2000; Focken et al., 2006). Paramoecium and Stylonychia are the most common forms of freshwater infusorians while Fabrea and Euplotes are of marine ones which are used in fish larval rearing. These protozoans can be mono cultured in small aquarium tanks filled with culture medium prepared by using lettuce, cabbage, banana peels, milk or liver extract in water. When the culture tank is kept in a cool place where natural diffused light is available, in a couple of days a film of slime infusorians will be formed on the water surface. In about 4 to 5 days, the culture reaches the peak density and will be ready for harvest. After 50\% harvesting, few drops of milk may be added and culture tank shall be filled with fresh water to sustain the culture for a week (Côrtes et al., 2013). The infusorians can also be cultured by boiling some dry paddy husk in water and using the solution as culture medium. This medium produces pure culture of Paramoecium species. The infusorians contain requisite nutrients for the normal development of fish larvae (Begum and Altaff, 2002).

Rotifers:

Rotifers are an important group of live food organisms for use in aqua hatcheries. About
2,500 species of rotifers have been reported from global freshwater, brackish water, and seawater. Brachionus plicatilis is the most known form of all rotifers and serve as an ideal starter diet for early larval stages of many fish and prawn species in marine as well as freshwater. B. plicatilis is the species used most commonly to feed fish larvae in hatcheries around the world (Maruyama etal., 1997). It is a euryhaline species, small and slows swimming, with good nutritional value. It is highly amenable to mass culture because of parthinogenic development and tolerance to a wide variety of environmental conditions. The different strains of the species of Brachionus plicatilis show variation in their sizes. Depending on the mouth size of the larvae of cultured organisms, small (50 to 100 $\mu \mathrm{m})$ or large (100 to $200 \mu \mathrm{m})$ rotifers are used. The rotifer, Brachionus plicatilis and Brachionus rotundiformis, have been indispensable as a live food for mass larval rearing of many aquatic organisms (Maruyama et al., 1997). The nutritional value of rotifers for larval fish depends on the rotifers' food source. Highly unsaturated fatty acids (HUFA) are essential for the survival and growth of finfish larvae. Rotifer feeds containing DHA (docosahexaenoic acid, 22:6n3), and EPA (eicosapentaenoic acid, 20:5n-3) can be valuable for marine fish larvae. Depending upon their food source, rotifers are composed of about 52 to $59 \%$ protein, up to $13 \%$ fat and $3.1 \%$ n-3 HUFA. High nutritional value of rotifers is of major importance for survival and growth of the fish larvae, and several cultivation techniques, including feeding with different algae, baker's yeast and artificial diets are used to improve their nutritional quality. Maintaining large cultures of rotifers and their production on a 
predictable basis is a major problem. The food of rotifers appears to be the key element in their mass production. Currently, fresh baker's yeast is mostly used as the main diet ingredient for rotifers. However, supplementation of baker's yeast with microalgae and vitamin $\mathrm{C}$ improve the nutritional quality of rotifers (Hirayama, 1987)

To get pure culture of Brachionus plicatilis, first stock culture has to be developed. For stock culture Brachionus plicatilis should be collected from the wild sources such as stagnant salt water/brackish water bodies and fed with yeast at $200 \mathrm{ppm}$ or Chlorella at a cell density of $10 \times 10^{6}$ cells $/ \mathrm{ml}$. Serially the test tube cultures should be diluted daily through several large test tubes and gradually the volume could be increased up to 1 to 2 litre beakers. These stock cultures usually contain 100 to 150 individuals/ml and are used as inoculums for mass culture. Normally, Brachionus plicatilisis mass cultured in 10 to 15 ppt saline water, where maximum reproduction occurs. Among the several methods, continuous culture method is extensively used. In this method, after fertilization of the culture tank with ammonium sulphate (100 g/1000 L), single super phosphate $(10 \mathrm{~g} / 1000 \mathrm{~L})$ and urea $(10 \mathrm{~g} / 1000 \mathrm{~L})$, the tank is inoculated with Chlorella. As Chlorella reaches its peak density $\left(10 \times 10^{6}\right.$ to $20 \times 10^{6}$ cells $\left./ \mathrm{ml}\right)$, tank is refertilized with the same medium as was initially used. When Chlorella cells are depleting, Baker's yeast is introduced at the rate of $1.0 \mathrm{~g} / \mathrm{million}$ Brachionus plicatilis/day. When Brachionus plicatilis population reaches 100 to 150 individuals $/ \mathrm{ml}$, about $25 \%$ of culture is harvested and transferred to the another tank. This procedure helps in uninterrupted supply of Brachionus plicatilis for aqua hatcheries. In order to maintain long term culture in the same tank, about $25 \%$ water is replaced from tank bottom with fresh filled water at an interval of 5 days (Maruyama et al., 1997).

\section{Cladocerans:}

Cladocerans are important group of predominantly freshwater zooplankton consisting of mostly female population resulting from parthinogenic development. Daphnia, Moina and Ceriodaphnia are an important food source in the freshwater aquaculture and ornamental fish industry. These cladocerans are distributed in freshwater ponds, tanks and lakes, all over the world. They swim by rapid jerks of the two large antennules. Daphnia contains a broad spectrum of digestive enzymes such as proteases, peptidases, amylase, lipase and even cellulase which serve as exoenzymes in the gut of fish and prawns. Daphnia being larger in size than Moina, it serves as live food for advanced stages of fishes. Moina are primarily inhabitants of temporary ponds or ditches. It is smaller in size ( 0.5 to $2 \mathrm{~mm}$ ) than Daphnia containing 70\% more protein and hence an ideal replacement for Artemia in aqua hatcheries. Moina has also been extensively utilized as live food in many hatcheries and in the maintenance and culture of aquarium fishes of commercial importance (Martin et al., 2003). Cladocerans have the advantage of high reproduction rates, wide temperature tolerance and the ability to thrive on phytoplankton and organic wastes. Being mainly freshwater zooplankton, most of the cladocerans do not tolerate salinities higher than 3 ppt., and are generally not found in brackish water. Das et al. (2012) reported that the Diaphanosoma celebensis a euryhaline 
cladoceran species which tolerate salinity range of 1-42 ppt and has a size range of 400 to $800 \mu \mathrm{m}$. This species has been successfully cultured in backyard hatcheries and there is a growing use of this species in fish larval rearing. Other marine cladoceran species are Evadne tergestina, Penilia avirostris and Podon polyphemoides and are considered as promising species for mass culture.

The cladoceran Moina macrocopa has been used in Southeast Asia as feed for sea bass fry immediately after weaning from Artemia and prior to feeding minced fish flesh. A related cladocera, Moina salina, has been used in finfish culture. The nutritional content of Moinavaries considerably depending on their age and the type of food they consume. The protein content of Moina usually averages $50 \%$ of the dry weight. The total amount of fat per dry weight is $20-27 \%$ for adult females and $4-6 \%$ for juveniles. In ornamental fish culture, Moina used to be the most common live food organism for feeding fish larvae. The nutritional value of cladocerans depends strongly on the chemical composition of their food source. The freshwater species of cladocerans are not suitable prey organism for marine organisms because of their low content of essential fatty acids, and in particular (n-3) HUFA (Martin et al., 2003).

For culture of Moina, stock culture has to be developed by collecting Moina from natural ponds and tanks and maintained in $20 \mathrm{ml}$ glass tube containing $10 \mathrm{ml}$ of filtered water and fed with yeast at $200 \mathrm{ppm}$ or Chlorella at a cell density of $10 \times 10^{6}$ cells $/ \mathrm{ml}$. Each reproductively active Moina produces 8 to 10 off springs in about $24 \mathrm{~h}$. The test tube culture is diluted daily through several $100 \mathrm{ml}$ beakers. The volume should be increased to 1 to 2 litre beakers. Feeding has to be continued in similar manner as in the test tube culture. After 4 to 5 days, these cultured Moina are used as inoculum in mass culture tanks. In mass culture methods, the culture tanks are treated with groundnut oil cake (75 ppm), single super phosphate $(20 \mathrm{ppm})$ and urea ( 8 ppm). After fertilization, the tank is inoculated with Chlorella or mixed phytoplankton. When algal blooms are developed within 3 to 4 days, Moina is inoculated at 40 to 50 nos./L. Moina multiples rapidly, feeding on phytoplankton blooms, bacteria and small particles. It attains a peak density of 20,000 to 25,000 nos./L in 5 to 7 days after inoculation. After attaining peak density, it is regularly harvested to feed the larval stages. As a result of Moina multiplication and reduction of nutritional status of water, Chlorella concentration declines. In order to maintain optimum Chlorella concentration, partial water exchange from the tank bottom and refertilization with groundnut oil cake (75 ppm) is done at an interval of 4 to 5 days after commencement of culture. After first harvesting of Moina, partial water exchange from the tank bottom and re-fertilization with groundnut oil cake (75 ppm) has to be done at an interval of 4 to 5 days. Ceriodaphnia cornuta is also can be produced in high density following similar culture method. Moina and Ceriodaphnia are smaller in size than Daphnia and contain 70\% more protein. They are used as an Artemia replacement feed in the culture of rainbow trout, salmon, striped bass Lates calcarifer, Macrobrachium rosenbergii and for tropical ornamental fish production (Mehraj-Ud-Din and Altaff, 2010).

\section{Copepods:}

Copepods are one of the large and diverse groups of animals belonging to the class Crustacea and include more than 10,000 
different species inhabiting in many different ecological niches. Copepods occur abundantly in most of marine and freshwater systems. Many copepod species are parasitic; others swim freely as planktonic forms, while still others are benthic or meiobenthic forms. Few free-living copepods exceed $2 \mathrm{~mm}$ in length as adults. Three major groups of free-living copepods are the Calanoida, primarily free swimming planktonic animals, the Cyclopoida, which may be planktonic or demersal, and the Harpacticoida, which are entirely benthic. Copepods with little exception are sexually reproducing and pass through many distinct larval stages. They emerge from an egg as nauplii, usually 100-150 $\mu \mathrm{m}$ in length. After six nauplius stages (N1 to N6), with growth between each stage, the body shape changes and a series of usually six copepodid stages follow (C1 to C6). The last of these stages is the adult in which different sexes can be identified (Altaff, 2003).

Copepods are natural feed for larvae and juveniles of many finfish and crustaceans and it is generally believed that copepods can meet the nutritional requirements of fish larvae (Evjemo et al., 2003). In the wild, most marine fish larvae feed on copepod eggs and nauplii during the first few weeks of life. Because some species of copepods have very small size larvae and can have very high levels of HUFAs and other essential nutrients, they are an excellent food source for first-feeding larvae. In fact, a number of marine larval fish cannot be reared using rotifers as the first feed but have been reared on either laboratory reared or wild caught copepod nauplii. Feeding trials with several species, such as the turbot and red snapper, have shown that when offered mixed plankton diets, young larvae consume more copepod nauplii than rotifers and prefer copepod nauplii because of the differences in size and swimming patterns of the two prey types. Consequently, there is considerable interest in the use of copepods as feed sources for small marine larval fish. Copepods are cylindrical with a trunk comprised of 10 segments, consisting of head, thorax and abdomen. Adult copepods size range from 0.5 to $5.0 \mathrm{~mm}$. Main suborders of copepods found in brackishwater are calanoids (Acartia, Calanus and Pseudocalanus spp.), harpacticoids (Tisbe and Tigriopus spp.), and cyclopoids. Herbivorous copepods are primarily filter feeders and typically feed on very small particles. But they can feed on larger particles, which give them an advantage over the rotifers. Copepods can also eat detritus. They differ from Artemia and rotifers in that they do not reproduce asexually. Copepods mate after maturing and female produces 250 to 750 fertilized eggs (rotifers produce 15 to 25 per female). The copepod life span is 40 to 50 days ( 5 to 12 days for rotifers), and it has a longer generation time ( 1 to 3 days for the rotifer and 7 to 12 days for the copepod). In contrast to rotifers, copepods are more difficult to culture on a commercial basis. Only a few species of copepods, such as Tigriopus japonicus, have been mass cultured successfully. Even this technique employs the combination of rotifer culture and the use of baker's yeast or omega-3 yeast as feed. There are outdoor production systems that can produce large numbers of copepods, however, these systems are very inefficient in terms of number of copepods per litre of culture water. For developing copepod culture protocol one should have adequate knowledge about food and feeding habits and reproductive biology of the species under consideration for culture. 
Aspects of copepod reproduction such as life span, maturity, active reproductive phase, mating, spermatophore transfer, fecundity, remating, embryonic and larval development are essential for achieving desired level of culture density larvae (Evjemo et al., 2003). Breeding biology of freshwater Copepoda Heliodiaptomus viduus (Gurney) and Sinodiaptomus (Rhinediaptomus) indicus and their prospects as live food organisms was reported by Altaff (2003) and Dharani and Altaff (2004), while mass culture of a freshwater cyclopoid, Thermocyclops decipines was reported by Altaff and Sivakumar (2004). Considerable work needs to be done on culture and harvest techniques before copepods become as widely used as rotifers. One interesting advantage of copepods is that under appropriate conditions some species will produce resting eggs similar to that of Artemia. So once commercial techniques are developed, copepod eggs could be collected in large numbers and stored for months, like Artemia cysts. Photoperiod and temperature largely determine the production of copepod resting eggs. Laboratory production of these eggs is possible, but has not yet proved to be economically feasible (Dharani and Altaff, $2004 \mathrm{~b}$ ). It is hoped that using copepods as a food source can improve the culture of a variety of species by reducing the size variability and mortality. The use of copepods, especially the harpacticoid, is well documented in marine fish culture. Prospects of Onychocamptus bengalensis as live feed for marine fish larvae are proposed by Saboor and Altaff (2005). The Japanese have routinely cultured the copepods Tigriopus and Acartia for rearing fish larvae approximately $7 \mathrm{~mm}$ in length. The growth and biochemical composition of Coryphaena hippurus larvae that were fed with copepod (Euterpina acutifrons) survived well under stressful conditions. A system for the mass culture of a benthic marine harpacticoid copepod, described by Sun and Fleeger (1995), found to be useful for aquaculture. Other species of copepods considered to be promising for mass culture are Acartia clausi, Acartia longiremis, Eurytemora pacifica, Euterpina acutifrons, Oithona brevicornis, Oithona similis, Pseudodiaptomus inopinus, Pseudodiaptomus marinus, Microsetella norvegica and Sinocalanus tenellus (Stottrup, 2006). Sun and Fleeger (1995) reported that copepodid and adult stages of the marine copepods Temora longicornis and Eurytemora sp. had a total lipid content varying between $7 \%$ and $14 \%$ of dry weight (DW). The predominant fatty acids of all copepods were docosahexaenoic acid (DHA; 22:6n-3), eicosapentaenoic acid (EPA; 20:5n-3) and the saturated fatty acid 16:0. In Temora longicornis and Eurytemora sp., DHA constituted 26-42\%, EPA 15-24\% and 16:0 8$12 \%$ of total fatty acids. In Calanus finmarchicus, the DHA content ranged between $21 \%$ and $32.5 \%$, whereas the content of EPA and 16:0 was $15-21 \%$ and $9-15 \%$ of total fatty acids, respectively. The sum of $n-3$ HUFA was highest in Temora longicornis and Eurytemora sp. (55-62\% of total fatty acids) and lowest in Calanus finmarchicus (38-47\%). The protein content of various copepods varied between $52.4 \%$ and $57.6 \%$ of dry weight. Biochemical profile of freshwater copepods was reported by Evjemo et al. (2003). The establishment of sustainable mass culture and fractionation methods for obtaining different size live prey for marine fish larvae could boost the mariculture industry. Nevertheless, copepod production in a saltwater pond system has indicated to be a 
reliable method for achievement of natural prey in starter feeding of marine fish larvae (Van der Meerena et al., 2014).

\section{Conclusion}

For sustainable aquaculture, production of quality seeds of finfish and shellfish is imperative and it is possible only by using suitable live feed for rearing their larvae. Though biology of many zooplankton is reported, their mass culture technology is yet to be established for species other than algae and Brachionus plicatilis. There are many potential species belonging to protozoans, marine cladocerans and copepods which could be ideal live feed in aqua-hatcheries. To cater the need of rearing marine fish larvae with small mouth, there should be more research on free living copepods which offer wide size range and nutritive value to the commercially important finfish larvae.

\section{Acknowledgement}

The author is thankful to the Management of the AMET University for providing facilities to carry out this work and also to the DBT, Govt. of India for funding a project (BT/PR30019/AAQ/3/929/2018).

\section{References}

Altaff K. (2003) Breeding biology of the freshwater copepod, Heliodiaptomus viduus (Gurney) and its prospects as live food organism. Pakistan J. Sci. Indust. Res.. 46: 180-187.

Altaff K and Sivakumar K. (2004) Mass culture of freshwater cyclopoid Thermocyclops decipines. J. Exp. Zool. India. 6: 237-243.

Begum DI and Altaff K. (2002) Biochemical profile of laboratory cultured freshwater protozoans. J. Aquat. Biol. 17: 47-49.

Bengtson DA. (2003) Status of marine aquaculture in relation to live prey: Past, present and future. In: Live Feeds in Marine Aquaculture, (eds.) Josianne GS and Lesley AM), Blackwell Science Ltd, U.K. pp. 1-16.
Brown MR, Jeffrey SW, Volkman JK and Dunstan GA. (1997) Nutritional properties of microalgae for mariculture. Aquaculture. 151: 315-331.

Conceição L, Pinto W, Siguero I, Urrutia, PFJ, Moyano and Yúfera, M.(2016) Do we need specific weaning diets for larvae of fast growing marine fish species? Asian-Pacific Aquaculture 2016, April 26th-29th, Surabaya, Indonesia. pp. 1-44.

Côrtes G, Tsuzuki MY and Melo EMC. (2013) Monoculture of the ciliate protozoan Euplotes sp. (Ciliophora; Hypotrichia) fed with different diets. Maringa. 35: 15-19.

Das PS, Mandal C, Bhagabati SK, Akhtar MS and Singh SK. (2012) Important live food organisms and their role in aquaculture. In: Frontiers in Aquaculture, (ed.) Munilkumar, Sukham Narendra Publishing House, pp. 69-86.

Dharani G and Altaff K. (2004 a) Life cycle of a copepod. In: A Manual of Zooplankton, (ed.) Altaff K., Department of Zoology, The New College, Chennai, India, pp. 66-75.

Dharani G and Altaff K. (2004 b) Ultrastructure of subitaneous and diapausing eggs of planktonic copepod Sinodiaptomus (Rhinediaptomus) indicus. Curr. Sci. 87: 109-112.

Dhert P. (1996) Rotifers. In: Manual on the production and use of live food for aquaculture, (eds.) Lavens P. and Sorgeloos P., FAO Fisheries Technical Paper, vol. 361. FAO, Rome, pp 49 -78.

Dhert P and Sorgeloos P. (2003) Live feeds in aquaculture, aquaculture towards the $21^{\text {st }}$ Century, (eds.) Nambiar KPPand Tarlochan Singh), Infolish, Kuala Lumpur, Malaysia, pp 209-219.

Eryalcin KM. (2018) Effects of different commercial feeds and enrichments on biochemical composition and fatty acid profile of rotifer (Brachionus plicatilis, Müller 1786) and Artemia franciscana. Turk. J. Fish. Aquat. Sci. 18: 81-90

Evjemo J0, Reitan KI and Olsen Y. (2003) Copepods as live food organisms in the larval rearing of halibut larvae (Hippoglossus hippoglossus L.) with special emphasis on the nutritional value. Aquacult. 227: 191-210.

Focken U, Schlechtriem C, Garc A, Puello-cruz A and Becker K. (2006) Panagrellus redivivus mass produced on solid media as live food for Litopenaeus vannamei larvae. Aquacult. Res. 37: 1429-1436.

Hirayama, K. (1987) A consideration of why mass culture of the rotifer Brachionus plicatilis with baker's yeast is unstable. Hydrobiol. 147: 269-270. 
Kar S, Das P, Das U, Bimola M, Kar D and Aditya G. (2017) Culture of the zooplankton as fish food: Observations on three freshwater species from Assam, India. AACL Bioflux. 1: 1210-1220.

Lavens P and Sorgeloos P. (1996) Manual on the production and use of live food for aquaculture. FAO Fisheries Technical Paper, 361. Rome.

Martin L, Arenal A, Fajardo J, Pimental E, Hidalgo L, Pacheco M, Garcia C and Santiesteban D. (2003) Complete and partial replacement of Artemia nauplii by Moina micura during early post larval culture of white shrimp Litopenaeus schmitti. Aquacult. Nutr. 12: 89- 96.

Maruyama I, Nakao T, Shigeno I, Ando Y and Hirayama K. (1997) Application of unicellular algae Chlorella vulgaris for the mass culture of marine rotifer Brachionus. Hydrobiol. 358: 133-138.

Mehraj-Ud-Din W and Altaff K. (2010) Culture of zooplankton for rearing fish larvae. Pollution Res. 29: 91-93.

Muller-Feuga A and Moal J and Kaas R. (2003) The microalgae of aquaculture: In: Live Feeds in Marine Aquaculture. (Eds.) Støttrup JG and McEvoy LA., Blackwell Publishing Company 9600 Garsington Road, Oxford OX4 2DQ UK. 206- 252.

Nagano N, Iwatsuki Y, Kamiyama $\mathrm{T}$ and Nakata $\mathrm{H}$. (2000) Effects of marine ciliates on survivability of the first feeding larval sturgeon fish, Paracanthurus hepatus: laboratory rearing experiments. Hydrobiol. 432: 149-157.

Olivotto I, Capriotti F, Buttino I, Avella AM, Vitiello V, Maradonna F and Carneval O. (2008) The use of harpacticoid copepods as live prey for Amphiprion clarkia larviculture: Effects on larval survival and growth. Aquacult. 274: 347-352.

Olivotto I, Tokle NE, Nozzi VL, Cossignani L and Carnevali O. (2010) Preserved copepods as a new technology for the marine ornamental fish aquaculture: A feeding study. Aquacult. 308: 124-131.

Paray BA and Al-Sadoon MK. (2016) Utilization of organic manure culture of cladocerans, Daphnia carinata, Ceriodaphnia cornuta and copepod Thermocyclops decipiens under laboratory conditions. Indian J. Mar. Sci. 45: 399 - 404.

Peter C. (1996) Microalgae. In: Manual on the Production and Use of Live Food for Aquaculture, (eds.) Lavens P.and Sorgeloos P.), FAO Fisheries Technical Paper, vol. 361. FAO, Rome. pp. 7-44.

Rajkumar M and Kumaraguruvasagam KP. (2006) Suitability of the copepod, Acartia clausi as a live feed for Seabass larvae (Lates calcarifer Bloch):
Compared to traditional live-food organisms with special emphasis on the nutritional value. Aquacult. 261: 649-658.

Rasdi NW and Qin J G. (2016) Improvement of copepod nutritional quality as live food for aquaculture: A review. Aquacult. Res. 47: 1-20.

Saboor Abdus and Altaff K. (2005) Diversity of Zooplankton of Adyar estuary. Poll. Res. 24: 135-142.

Santhanam P and Perumal P. (2012) Evaluation of the marine copepod Oithona rigida Giesbrecht as live feed for larviculture of Asian seabass Lates calcarifer Bloch with special reference to nutritional value. Indian J. Fish. 59: 127-134.

Sargent JR, McEvoy LA and Bell JG. (1997) Requirements, presentation and sources of polyunsaturated fatty acids in marine fish larval feeds. Aquacult. 155: 117-127.

Stottrup, J G. (2006) A Review on the status and progress in rearing copepods for marine Larviculture. In: Advantages and disadvantages among Calanoid, Harpacticoid and Cyclopoid copepods. (eds.) Elizabeth CSL., Denis RM., Mireya TS., Martha GNL., David AVC., Ana CPC. and Armando GO.), Advances en Nutrition Acuicola VIII. VIII Symposium International de Nutrition Acuicola.1517 November. Universidad Autonomy de Nuevo Leon, Monterrey, Nuevo Leon, Mexico. pp. 62- 83.

Stottrup JG and McEvoy LA. (2003) Live feeds in marine aquaculture. Ames, Iowa, USA: Iowa State Press, pp. 336.

Sun B and Fleeger JW. (1995) Sustained mass culture of Amphiascoides atopus, a marine harpacticoid copepod in a recirculating system. Aquacult. 136: 313-321.

Van der Meerena T, Karlsena 0, Liebig PL and MangorJensenc A. (2014) Copepod production in a saltwater pond system: A reliable method for achievement of natural prey in start-feeding of marine fish larvae, Aquacult. Engineer. 62:17-27.

Verschuere L, Rombaut G, Sorgeloos P and Verstraete W. (2000) Probiotic bacteria as biological control agents in aquaculture. Microbiol. Mol. Biol. Rev. 655-671.

Wang Y, Chen P, Dhams H, Yeh S and Chiu Y. (2016) Comparing methods for measuring phytoplankton biomass in aquaculture ponds, Aquacult. Environ. Interact. 8: 665-673.

White LA, Newman MC, Cromwell GL and Lindemann MD. (2002) Brewers dried yeast as a source of mannan oligosaccharides for weanling pigs. J. Animal Sci. 80: 2619-2628. 